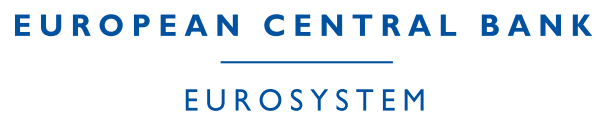

\title{
WHO NEEDS CREDIT AND WHO GETS CREDIT IN EASTERN EUROPE?
}

by Martin Brown, Steven Ongena, Alexander Popov and Pinar Yesin

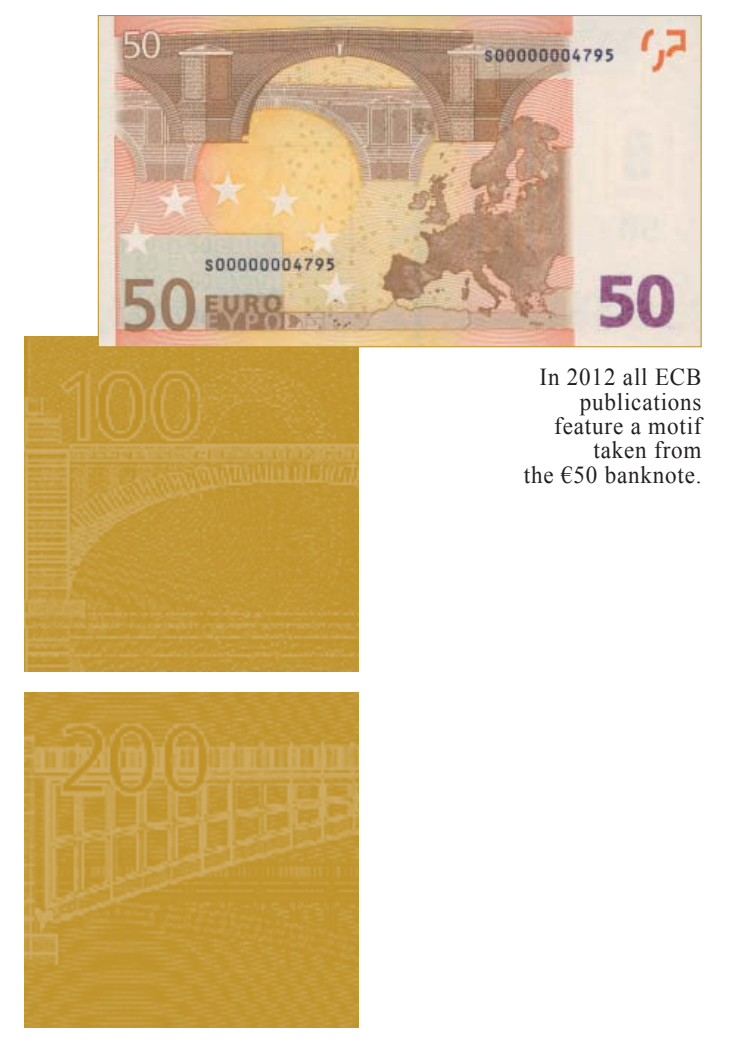

NOTE: This Working Paper should not be reported as representing the views of the European Central Bank (ECB). The views expressed are those of the authors and do not necessarily reflect those of the ECB. 


\section{Acknowledgements}

Paper presented at the 51st Panel Meetings of Economic Policy in Madrid. We thank Tullio Jappelli, three anonymous referees, as well as reader session and seminar participants at the Swiss National Bank for helpful comments. Any views expressed are those of the authors and do not necessarily reflect those of the Swiss National Bank or the European Central Bank.

\section{Martin Brown}

at Swiss National Bank, Börsenstrasse 15, 8022 Zürich, Switzerland and CentER - Tilburg University; e-mail: martin.brown@snb.ch

\section{Steven Ongena}

at CentER-Tilburg University, Warandelaan 2, 5037 AB Tilburg, Netherlands and CEPR; e-mail: steven.ongena@tilburguniversity.nl

\section{Alexander Popov}

at European Central Bank, Kaiserstrasse 29, D-60311 Frankfurt am Main, Germany; e-mail: alexander.popov@ecb.europa.eu

\section{Pinar Yesin}

at Swiss National Bank, Börsenstrasse 15, 8022 Zürich, Switzerland; e-mail: pinar.yesin@snb.ch

(C) European Central Bank, 2012

\section{Address}

Kaiserstrasse 29, 60311 Frankfurt am Main, Germany

Postal address

Postfach 1603 19, 60066 Frankfurt am Main, Germany

\section{Telephone}

+496913440

\section{Internet}

http://www.ecb.europa.eu

\section{Fax}

+496913446000

All rights reserved.

ISSN 1725-2806 (online)

Any reproduction, publication and reprint in the form of a different publication, whether printed or produced electronically, in whole or in part, is permitted only with the explicit written authorisation of the ECB or the authors.

This paper can be downloaded without charge from http://www.ecb.europa.eu or from the Social Science Research Network electronic library at http://ssrn.com/abstract_id=1615476.

Information on all of the papers published in the ECB Working Paper Series can be found on the ECB's website, http://www.ecb.europa. eu/pub/scientific/wps/date/html/index.en.html 


\begin{abstract}
Based on survey data covering 8,387 firms in 20 countries we compare credit demand and credit supply for firms in Eastern Europe to those for firms in selected Western European countries. We find that firms in Eastern Europe have a higher need for credit than firms in Western Europe, and that a higher share of firms is discouraged from applying for a loan. The higher rate of discouraged firms in Eastern Europe is driven more by the presence of foreign banks than by the macroeconomic environment or the lack of creditor protection. We find no evidence that foreign bank presence leads to stricter loan approval decisions. Finally, credit constraints do have a real cost in that firms which are denied credit or discouraged from applying are less likely to invest in R\&D and introduce new products.
\end{abstract}

Keywords: Credit Constraints, Banking sector, Transition economies

JEL Codes: G21, G30, F34 


\section{Summary}

Based on survey data covering 8,387 firms in 20 countries we compare credit demand and credit supply for firms in Eastern Europe to those for firms in selected Western European countries.

We find that, while 30\% of firms do not need credit in Eastern Europe, their need for credit is higher than in Western Europe. The firm-level determinants of credit needs in Eastern Europe are quite similar to that in Western Europe: Firms with alternative financings sources, i.e. government-owned, foreign-owned and internally financed firms, are less likely to need credit. Small firms are also less likely to demand credit than larger firms, suggesting that they may have limited investment opportunities.

We find that a higher share of firms is discouraged from applying for a loan in Eastern Europe than in Western Europe. Firms in Eastern Europe seem particularly discouraged by high interest rates compared to firms in Western Europe, with collateral conditions and loan application procedures also more discouraging. The higher rate of discouraged firms in Eastern Europe is related to a stronger reluctance of small and financially opaque firms to apply for a loan compared to Western Europe. While many discouraged firms correctly anticipate that their loan applications would be rejected, a large majority of discouraged firms seem to be creditworthy.

At the country-level we find that the higher rate of discouraged firms in Eastern Europe is driven more by the presence of foreign banks than by the macroeconomic environment or the lack of creditor protection. We find no evidence that foreign bank presence leads to stricter loan approval decisions.

Our findings suggest to policy makers that the low incidence of bank credit among firms in Eastern Europe, compared to Western Europe, is not driven by less need for credit or banks' reluctance to extend loans. The main driver seems to be that many (creditworthy) firms are discouraged from applying for a loan, due to high interest rates, collateral conditions and cumbersome lending procedures. As discouragement is particularly high among small and opaque firms, as well as in countries with a strong presence of foreign banks, it seems that firms perceive lending standards to have become more reliant on "hard information" with the entry of foreign banks. However, as loan rejection rates are not related to foreign bank presence, it seems that firms' perceptions of the likely lending conditions may be too pessimistic. Thus more transparency about credit eligibility and conditions may improve credit access, particularly in countries with a high presence of foreign banks. 


\section{Introduction}

Limited access to bank credit, in particular for small enterprises, is viewed by many policy makers and academics as a major growth constraint for emerging and developing economies. ${ }^{1}$ As a result, substantial national and multinational resources have been devoted to improving credit availability around the world. In 2008, for example, the International Finance Corporation (IFC), a part of the World Bank Group, invested 310 Million dollars in 230 projects worldwide, with the aim of improving access to financial services. The IFC invested over 80 Million US\$ alone to promote small enterprise credit. ${ }^{2}$

The transition economies of Eastern Europe have undertaken particularly strong efforts to reform their banking sectors and enhance the availability of private credit. ${ }^{3}$ In almost all countries, state-owned banks have been privatized and foreign bank entry has been encouraged (EBRD (2006)). The legal environment for secured and unsecured lending has been improved, e.g., by establishing centralized pledge registries, or by improving the position of creditors in bankruptcy procedures (EBRD (2008)). Information sharing between creditors through private credit bureaus or public credit registries has also been introduced in most Eastern European countries (Brown, Jappelli and Pagano (2009)). These domestic institutional changes have been strongly encouraged and supported by multilateral institutions. In addition international financial institutions have provided substantial

\footnotetext{
${ }^{1}$ Levine (2006) summarizes the country-, industry- and firm-level evidence documenting the positive impact of financial development and economic growth. Beck, Demirgüç-Kunt, Laeven, and Levine (2008) find that financial sector development exerts a disproportionately positive effect on small firms.

${ }^{2}$ http://www.ifc.org/ifcext/gfm.nsf/AttachmentsByTitle/A2F-HighlightsReport2008/\$FILE/A2F-

HighlightsReport2008.pdf.

${ }^{3}$ Our definition of Eastern Europe follows that of the European Bank for Reconstruction and Development (EBRD) and includes the following 15 countries: Albania, Bulgaria, Bosnia, Croatia, Czech Republic, Estonia, Hungary, Latvia, Lithuania, Macedonia, Poland, Romania, Serbia, Slovak Republic, and Slovenia.
} 
funding to the financial sector in Eastern Europe. In 2008, the European Bank for Reconstruction and Development (EBRD) alone held assets of over 7 billion euro towards financial institutions across the region. ${ }^{4}$

Despite the substantial resources invested in improving credit availability in Eastern Europe, less than half of the firms in the region actually have bank credit (see Figure 1). The use of bank credit does however vary strongly across the region. The share of firms with a bank loan varies from 29 percent in Macedonia to more than 66 percent in Croatia. While the use of bank credit seems to be low in Eastern Europe, it is only slightly below that of selected Western European countries. Indeed, four countries in Eastern Europe (Croatia, Slovenia, Bosnia, and Hungary) have loan incidences which exceed the average for the sample of Western European firms.

Insert Figure 1 here

Figure 1 gives rise to three important questions for policy makers, when considering future policies to enhance credit availability:

First, to what extent is the low incidence of bank credit in Eastern Europe the result of supply-side credit constraints or low credit demand? The similar levels of bank credit in

\footnotetext{
${ }^{4}$ EBRD Annual Report 2008, http://www.ebrd.com/pubs/general/ar08.htm. The figure includes investment in Eastern Europe and other transition countries.
} 
Eastern and Western Europe suggest that at least some firms which do not have bank credit, may actually not need or want credit. Knowing the extent to which firms in the region are actually credit constrained is crucial for planning future public interventions towards financial sector development.

Second, to what extent are firms which need credit denied credit or discouraged from applying for a loan in the first place? Are small firms more often discouraged from applying for credit than actually denied credit as recent evidence has shown for both developed (Cole 2008) and developing countries (Chavrakarty and Xiang (2009))? Knowing to what extent firms are discouraged or denied credit is important for choosing the type of public interventions towards improving credit availability.

Third, how are credit constraints related to differences in the structure and institutions of the financial sector across countries? For example, are small firms more likely to be discouraged from applying for credit, or denied credit in countries where foreign-owned banks are dominant? Knowing how structural and institutional changes to the banking sector may affect credit discouragement and denial is crucial for assessing their benefits as well as for devising measures to limit their potential adverse effects.

In this paper, we examine these three questions, using survey data covering 5,040 firms in 15 Eastern European countries and 3,347 firms in 5 Western European countries. We first examine which firms in which countries need bank credit. We then examine which of the firms in need of bank credit are discouraged from applying for credit and which firms are denied credit when they apply. Finally, we study how loan discouragement and loan rejection are related to bank-ownership, creditor rights and credit information sharing across countries. 
We find that, while $30 \%$ of firms do not need credit in Eastern Europe, credit need is still higher in Eastern Europe than in Western Europe. The structure of credit needs in Eastern Europe is quite similar to that in Western Europe: Firms with alternative financings sources, i.e. government-owned, foreign-owned, and internally financed firms, are less likely to need credit in both regions. The lower credit needs of small firms are more pronounced in Eastern than in Western Europe.

While firms in Eastern Europe are more likely need credit, they are less likely to actually receive a loan. The higher rate of discouraged firms in Eastern Europe seems to be driven by a stronger reluctance of small and financially intransparent firms to apply for a loan compared to Western Europe. While many discouraged firms correctly anticipate that their loan applications would be rejected, a large majority of discouraged firms seem to be creditworthy.

At the country-level we find that the higher rate of discouraged firms in Eastern Europe is partly driven by the presence of foreign bank rather than differences in the macroeconomic environment or creditor protection. However, we find no evidence that foreign bank presence leads to stricter loan approval decisions.

Our findings suggest to policy makers that the low incidence of bank credit among firms in Eastern Europe, compared to Western Europe is not driven by lower demand for credit or by banks' reluctance to extend loans. The main driver seems to be that many (creditworthy) firms are discouraged from applying for a loan, due to high interest rates, collateral conditions, and cumbersome lending procedures. As discouragement is particularly high among small and opaque firms, as well as in countries with a strong presence of foreign banks, it seems that firms perceive lending standards to have become more reliant on "hard 
information" with the entry of foreign banks. However, as loan rejection rates are not related to firm transparency or foreign bank presence, it seems that firms' perceptions of the likely lending conditions may be too pessimistic. Thus more transparency about credit eligibility and conditions may improve credit access, particularly in countries with a high presence of foreign banks.

Our findings are also relevant for judging the potential impact of the current financial crisis on Eastern Europe, in particular, of a credit crunch due to capital outflows from the region. During the last decade, rapid credit growth in the region was strongly driven by foreign participation in and capital flows to the region's banking sector. For example, according to the Bank for International Settlements (BIS) Banking Statistics, consolidated foreign claims on banks in Emerging Europe rose from \$366 billion in September 2004 to \$1,588 billion in June 2008 on an immediate borrower basis. ${ }^{5}$ However, since the onset of the current financial crisis, capital flows to Emerging Europe, and particularly to banks in the region have been drying up dramatically. Indeed, according to the Institute of International Finance (IIF), Emerging Europe is the region most directly affected by the declining international capital flows. ${ }^{6}$ This severe contraction in refinancing of the region's banking sector immediately raises the question of which firms in Eastern Europe will most likely face tighter credit constraints and what the credit contraction implies for the economic performance of the entire region. Our results suggest that especially export-orientated firms,

\footnotetext{
${ }^{5}$ According to the BIS definition, Emerging Europe consists of the Eastern European countries in our sample, minus Slovenia, plus Belarus, Moldova, Montenegro, Turkey, and Ukraine.

${ }^{6}$ IIF Research Note "Capital Flows to Emerging Market Economies”, October 3, 2009

http://www.iif.com/press/press+119.php.
} 
which have the highest credit demand, may be hit hardest by a potential credit crunch, while smaller firms, with their lower demand for bank credit, may be less affected.

Our study is related to a growing body of literature which examines how banking sector structure and institutional development affect credit availability in Eastern Europe. Given that foreign banks now dominate the banking sector in many Eastern European countries, their impact on credit availability has come under particular scrutiny (de Haas and Lelyveld (2006)). Concerns remain that small and opaque firms can be serviced only poorly by foreign banks (Detragiache, Tressel, and Gupta (2008)), though the evidence is not unambiguous (Giannetti and Ongena $(2008,2009)){ }^{7}$ Further attention has been given to the impact of institutional and legal developments on credit availability. Brown, Jappelli, and Pagano (2009), for example, find that information sharing among banks increases perceived credit availability for firms, while Pistor, Raiser, and Gelfer (2000) show that transition countries with better creditor protection have larger aggregate credit levels. While several of the above studies examine firm-level accounting and survey data, they do not attempt to isolate firm-level credit demand from credit supply. Our paper complements the above studies by examining the determinants of credit demand, and distinguishing these from the determinants of credit supply.

Our paper further contributes to the literature on loan demand and discouragement by providing cross-country evidence. Most published work which examines loan demand and

\footnotetext{
${ }^{7}$ Using bank-level accounting data a complementary set of papers shows how financial sector liberalization has increased bank-efficiency in transition countries, e.g., Bonin, Hasan, and Wachtel (2005), and Fries and Taci (2005).
} 
discouragement by firms focus on a single country, i.e. the US, using the National Survey on Small Business Lending (Cole (1998); Cole (2008); and Han, Fraser, and Storey $(2009))^{8}$

Chakravarty and Xiang (2009) also study firm discouragement across 10 emerging economies employing the Investment Climate Surveys run by the World Bank in the late 1990s and early 2000s. They find differences across countries in the firm factors that drive discouragement. Our cross-country analysis across 15 Eastern and 5 Western European countries using the 2004/2005 BEEPS allows us to also examine how substantial differences in the banking structure and institutional environment between emerging and developed countries continue to affect firm discouragement.

The rest of the paper is structured as follows. We present the data in Section 2. We discuss our empirical results in Sections 3 and 4. Section 5 concludes with a summary of our findings and policy implications.

\section{Data}

Our firm-level data comes from the 2004/2005 wave of the Business Environment and Enterprise Performance Survey (BEEPS), administered jointly by the World Bank and the European Bank for Reconstruction and Development (EBRD). We exclude data from the 1999, 2002 and 2008 waves of this survey as they do not provide comparable information

\footnotetext{
${ }^{8}$ Discouragement of households from taking loans has also been studied for the US by Jappelli (1990) and Chakravarty and Scott (1999) and across regions in Italy by Guiso, Sapienza and Zingales (2004).
} 
on credit demand and supply. The 2004/2005 BEEPS surveyed, respectively, 5,040 firms from 15 Eastern European countries, 3,347 firms from 5 Western European countries, and 4,615 firms from 12 countries in the Commonwealth of Independent States (CIS) and Turkey. In order to not only examine credit demand and supply in Eastern Europe, but also to contrast it with credit demand and supply in Western Europe, our analysis is based on the Eastern European and Western European samples.

The 2004/2005 BEEPS asked firms about their experience with financial and legal constraints, as well as government corruption. The survey also includes questions about firm ownership, firm governance, firm activity and firm financing. The survey response rate was $36.9 \%$. The number of firms in our sample ranges from 200 in Bosnia to 1,197 in Germany.

The survey aimed to achieve representativeness in terms of the size of firms it surveyed: roughly two thirds of the firms surveyed are "small", i.e. they have less than 50 workers. 9 By design the survey only covers established firms, i.e. firms which have been in business for at least three years. This implies that our sample does not allow us to examine credit demand and supply for young or start-up firms. Moreover, our results are subject to sample selection, in the sense that we only observe firms which had sufficient internal or external funds to survive for at least three years.

\footnotetext{
${ }^{9}$ See http://www.ebrd.com/country/sector/econo/surveys/beeps.htm for a full description of the BEEPS surveys including survey methodology and questionnaires.
} 


\section{Indicators of credit demand and supply}

The survey questionnaire includes three questions about firm financing which allow us to identify whether firms need credit, whether they apply for creditor or are discouraged from doing so, and whether their loan applications are approved or rejected. In question Q46a, firms are first asked if they have a loan or not. Those firms without a loan are then asked in Q47b whether they (a) didn't apply for a loan or (b) applied for a loan, but the application was turned down or (c) have a loan application pending. Those firms that didn't apply for a loan are then asked in $\mathrm{Q} 47 \mathrm{~b}$ to list the main reasons why they did not do so. To this question there are multiple possible answers: (a) the firm does not need a loan, (b) application procedures are too burdensome, (c) collateral requirements are too high, (d) interest rates are too high, (e) informal payments are necessary, (f) the firm did not think their application would be approved.

Figure 2 provides an overview of the responses to these three survey questions for the Eastern European and Western European sample separately. The figure shows that for all three questions there was almost a $100 \%$ response rate, suggesting that the data from which we take our indicators of credit demand and supply are reliable.

Insert Figure 2 here

From the above questions we establish three indicators of credit demand and supply. 
The variable Need loan is a dummy variable which equals 0 for those firms which did not apply for a loan and their only reason for not doing so was because they did not need one. For all firms which did apply for a loan or which did not apply for a loan and stated another reason (besides not needing a loan) the variable Need loan equals $1 .^{10}$

The variable Discouraged is a dummy variable which equals 1 for those firms which did not apply for a loan and for which the variable Need loan equals 1 , and equals 0 for those firms which applied for a loan, i.e. those which either have a loan, had their application rejected, or have an application pending.

The variable Rejected is a dummy variable which equals 1 for those firms which applied for a loan but their application was turned down, and equals 0 for those firms which applied for a loan and have a loan. Firms with pending applications (74 of the 8,387 firms in our sample, i.e. less than $1 \%$ ) are treated as missing.

Table 1 presents summary statistics for our indicators of credit demand and supply by country and region. We find that a higher share of firms in Eastern Europe need a bank loan compared to Western Europe (70 versus 63 percent). Moreover, a higher fraction of those that need a loan are discouraged from applying for one (28 versus 12 percent). The fraction of firms that have their loan applications rejected is also slightly higher in Eastern Europe than in Western Europe ( 8 versus 5 percent). Table 1 also shows that there are substantial

\footnotetext{
${ }^{10}$ Note that those firms which did not apply for a loan could list multiple reasons for not doing so. According to our classification above which listed "Do not need loan" and another reason, e.g., "Interest rates are too high", is classified as needing a loan. Only these firms which provided "Do not need a loan" as a unique answer were classified as not needing a loan.
} 
cross-country differences in credit demand and supply across Eastern and also across Western Europe. In Eastern Europe the fraction of firms needing a loan varies between 56 percent in the Czech Republic and 78 percent in Croatia or Hungary. Throughout the region, discouragement rather than rejection of loan applications seems to be responsible for the substantial share of firms which need but do not have loans. The share of firms which need but do not apply for a loan varies from 52 percent in Macedonia to 9 percent in Slovenia. By contrast loan rejection rates are low (between 2 and 13 percent) in each country. In our (limited) sample for Western Europe we see that loan demand also varies strongly across countries (43\% in Portugal to $79 \%$ in Germany), while credit discouragement, and in particular loan rejection rates are low in all five countries.

Insert Table 1 here

In addition to our three main indicators of credit demand and supply, our analyses use three detailed indicators of why firms are discouraged from applying for loans. As mentioned above firms could provide multiple reasons for not applying for a loan. The variable Discouraged - procedures is a dummy variable which is equals to 1 for all firms that are discouraged and stated "application procedures are too burdensome" as one of these reasons. The variable Discouraged - interest is a dummy variable which is equal to 1 for all firms that are discouraged and stated "interest rates are too high" as one of their reasons for not applying for a loan. Finally, the variable Discouraged - collateral is a dummy variable 
which is equal to 1 for all firms which are discouraged and stated "collateral requirements are too high" as one of their reasons.

The summary statistics in Table 1 show that, in Eastern Europe, high interest rates are the most common reason for credit discouragement. Among those firms that need a loan, 17\% say that they are discouraged by interest rates, while $12 \%$ mention collateral conditions and $11 \%$ procedures as a reason for not applying for a loan. By contrast, in Western Europe, interest rates are less of a reason for discouragement than collateral conditions or application procedures.

\section{A. Firm-level determinants}

We expect that due to alternative financing opportunities, involving soft budget constraints and internal capital markets, firms with government or foreign ownership may be less likely to need (bank) credit, ceteris paribus. ${ }^{11}$ Also following the pecking-order theory of corporate finance we expect firms with higher retained earnings to display less need for bank credit, while young, small firms and privatized firms with fewer alternative financing sources may be more likely to need credit.

Given a firm's alternative financial sources, its need for bank credit will depend on its investment opportunities, which may be affected by the markets it operates in (exporting

\footnotetext{
${ }^{11}$ Loss-making government-owned enterprises in many transition economies initially relied heavily on direct subsidies (Kornai, 1979), reducing their need for external financing. However, later on these enterprises were increasingly also bailed out by inter-enterprise and even bank credit, demonstrating the possibly endogenous and varying nature of the soft budget constraint (Dewatripont and Maskin, 1995).
} 
vs. domestic), competitive pressure in these markets, as well as the business environment (taxation, red-tape, corruption; see Mauro (1995) for example).

The ownership aspect of the internal capital allocation in Gertner, Scharfstein and Stein (1994) leads to more monitoring than bank lending and an easier redeployment of assets of poorly performing projects. We therefore expect that small firms are more likely to be discouraged from applying for a loan, or more likely to have a loan application rejected, while loan applications and approvals should be more frequent for firms with foreign ownership, privatized firms, and exporters (as they may be the more easily monitored and successful firms that employ redeployable assets), ${ }^{12}$ as well as for audited firms and firms which regularly use bank accounts (because they have more credible financial information and need less monitoring; see also Kon and Storey, 2003 as well as Mester, Nakamura and Renault, 2007).

Confirming the above predictions recent empirical research by Brown, Jappelli, and Pagano (2009), Brown, Ongena, and Yesin (2009), and Ongena and Popov (2009) using the BEEPS data, and by Chakravarty and Xiang (2009) using the similar Investment Climate Survey data, has shown that firm size, age, ownership, activity, accounting standards, product market competition, bank use and internal financing, and obstacles to doing business affect credit access and credit terms.

\footnotetext{
${ }^{12}$ Empirical evidence based on firm-level panel data suggests that more productive firms enter export markets. Bernard and Jensen (1999) document among US firms that, in addition to having higher productivity, exporting firms also have higher employment, shipments, wages, and capital intensity than non-exporters. Clerides, Lach, and Tybout (1998) find that exporting firms have higher productivity levels on average than non-exporters in several developing countries.
} 
Following the above literature we relate our indicators of credit demand and supply to firmlevel indicators of firm size (Small firm), age (Age), ownership structure (Owner government, Owner foreign), privatization history (Privatized), owner gender (Owner female), export activities (Exporter), and accounting standards (Audited). We further feature the number of local product market competitors of the firm (Competitors), the share of firm earnings received through a bank account (Bank income), the share of working capital financed by retained earnings over the past 12 months (Internal finance), and an indicator of the sector in which the firm operates (by SIC 1-digit). Finally, we include the assessment of the severity of three growth obstacles, i.e. the tax rate (Tax), business licensing and regulations (Licensing \& permits), and corruption (Corruption).

The definitions of these firm-level variables are provided in the appendix. Summary statistics for our firm-level variables are presented in Table 2. The table shows that the firms in our Eastern European sample are similar in size and ownership to those in our Western sample. Not surprisingly, firms in Eastern Europe are more likely to be government-owned or privatized, and less likely to be audited than firms in our Western European sample. Firms in Eastern Europe also view the markets they operate in as less competitive, but their business environment as more cumbersome. Interestingly, firms in Eastern Europe are more likely to have exporting activities than firms in Western Europe and have a higher fraction of their income flowing through a bank-account.

Insert Table 2 here 
There is substantial cross-country variation within Eastern Europe. For example only 4 percent of the firms in Hungary are government-owned, compared to 16 percent of firms in Serbia; only 24 percent of the firms in Bulgaria and Romania export, compared to 47 percent of the Slovenian firms; and only 31 percent of the firms in Macedonia are audited while 84 percent are audited in Albania. Table 2 also shows substantial cross-country variation in our Western European sample. For example, only 36 percent of surveyed firms in Spain are audited, and only $16 \%$ percent of firms from Germany are exporters, while in the Irish sample 94 percent of firms are audited and 30\% of the firms export. These figures suggest that when examining cross-country credit demand and supply it is important to also control for differences in firm characteristics.

\section{B. Country-level determinants}

In environments with high levels of asymmetric information and weak investor protection, banks' ability to lend may be impeded even when funds are readily available (Khwaja, Mian and Zia (2007)). Moreover, agency problems may impede the issuing of equity (for example by banks) to foreign investors (Chari and Henry (2004)). Foreign banks may be even more reluctant than domestic financial intermediaries to lend to opaque borrowers. Foreign banks could poach depositors and safe borrowers from domestic banks while remaining unwilling to lend to local entrepreneurial firms. In addition, foreign acquisitions could disperse the "soft" information local lenders have accumulated.

As in Pistor, Raiser, and Gelfer (2000), de Haas and Lelyveld (2006), Giannetti and Ongena (2008), and Brown, Jappelli, and Pagano (2009), we therefore relate our two (inverse) indicators of credit supply (Discouraged, Rejected) to foreign ownership in the banking 
sector (Foreign banks), credit information sharing (Credit info), and creditors' rights (Creditor rights). We expect that credit supply will be positively related to creditor protection. The impact of foreign bank ownership on credit supply may, however, depend strongly on firm characteristics, with large and transparent firms benefiting more than small, opaque firms.

Besides these structural and institutional features of the banking sector, the macroeconomic environment within a country may affect the supply of bank credit. In particular higher domestic inflation may reduce bank credit, as has been shown by Boyd, Levine and Smith (2001) and confirmed by Fries and Taci (2002) for Eastern Europe. When examining the country-level determinants of credit supply we therefore control for the level of domestic consumer price Inflation.

The region of Eastern Europe has seen many radical reforms since the fall of communism in 1989 altering the structure of the economy, macroeconomic policy, law and regulation, and financial markets. Apart from widespread privatization of state-owned services and manufacturing industry, those fundamental changes also included for instance the break-up of the one-bank model (under which the central bank and the commercial banks were operated under the same authority) and the divestiture of a large share of commercial banks' assets to the private sector and foreign entities (EBRD (2006)).

However, advances in this direction were uneven across the region. Rapid banking reforms were sometimes followed by banking crisis and/or government recapitalization of banks 
(Hungary in 1991, Estonia in 1992, Latvia and Lithuania in 1995, and Bulgaria and the Czech Republic in 1996). ${ }^{13}$ The reform of the previously socialist-based legal system further resulted in a return to some form of pre-WWII state of law which in different parts of the region was derived from different legal systems (Nordic, French, or German). ${ }^{14}$ In addition, countries embarked on their reforms with different speed - in general, the Baltic states and the Vysegrad four (the Czech Republic, Hungary, Poland, and Slovakia) were much faster to liberalize their economies and their financial sectors than the countries in South-Eastern Europe. And while in most countries foreign entry in to the banking sector started relatively early, in South-Eastern Europe banking reforms were slower, and Slovenia for example allowed foreign bank entry only in 2001.

Finally, while the region has in general moved towards higher macroeconomic stability, some countries in the sample had a painful experience with inflation (Bulgaria in 1997) or even hyperinflation (Serbia in 1993-1994). For all those reasons, while the region has been relatively homogeneous in terms of economic and political experience during the past 20 years, with 10 of the 15 countries already EU members and the rest on their path to accession, we expect to take advantage of the still existing substantial variation in our country-level variables of interest.

Table 3 presents summary statistics for our country-level variables and confirms our expectation to find considerable variation in the macroeconomic and financial environment

\footnotetext{
${ }^{13}$ See Laeven and Valencia (2008).

${ }^{14}$ See La Porta, Lopez-de-Silanes, Shleifer, and Vishny (1998).
} 
not just between West and East, but also among countries in the region of Eastern Europe itself.

Insert Table 3 here

Not surprisingly, inflation is significantly lower in Western Europe than in Eastern Europe. Also, while low in Lithuania and Macedonia, it is in the double digits in Romania and Serbia. Foreign participation in the banking sector is higher in Eastern than in Western Europe, and foreign-owned banks control on average 72 percent of all bank assets. However, in Slovenia, Serbia and Macedonia less than 50\% of the banking sector assets are foreign-owned $(20.5 \%, 47.4 \%$, and $48.5 \%$, respectively). And even in some of the other countries lower-than-average foreign bank ownership stems from the fact that the largest bank in the country is domestically-owned (for example, in Latvia and Poland).

Information sharing in the banking sector is more prevalent in Western Europe than in Eastern Europe, while creditor rights seem to be stronger on average in Eastern Europe than in Western Europe. And while it is not clear that these can be easily linked to the origin of legal systems, differences still prevail within the region itself, with creditors' rights ranging from a low of 4 in Bosnia to a high of 9 in Albania, Latvia, and Slovakia, and the degree of information sharing ranging from 0 in Albania and Croatia to 5 in Bosnia, Estonia, Hungary, and Serbia. 


\section{Results}

In this section we present our analysis of credit demand and supply based on the BEEPS 2004/2005 survey. We first examine which firms need a loan. We then examine which firms that need credit are discouraged from applying for a loan or have their loan rejected. Finally, we relate differences in credit discouragement and rejection across countries to financial development, bank ownership and creditor protection.

\section{A. Which firms need credit?}

Table 4 presents results for four estimated models of credit demand. The dependent variable in this set of regressions is the dummy variable Need loan. The probit models reported in columns (1-2) examine the firm-level determinants of credit demand using the sample of firms from Eastern Europe and Western Europe respectively. Model (3) replicates the previous models using data for firms from both Eastern Europe and Western Europe. Model (4) compares the determinants of credit demand in Eastern Europe to that in Western Europe by using a linear regression in which we add interaction terms of firmlevel variables the region dummy Western Europe. ${ }^{15}$

Insert Table 4 here

\footnotetext{
${ }^{15}$ The ordinarily reported standard errors and marginal effects of interacted variables in non-linear models require corrections (Ai and Norton (2003)). We choose instead to linearize the model and estimate it using ordinary linear squares.
} 
The results in Model (1) suggest that within Eastern Europe small, government-owned, foreign-owned and internally financed firms are less likely to need credit, while old and exporting firms are more likely to need credit. The lower demand of government, foreignowned and internally financed firms confirms our predictions, as we these firms (may) have alternative financing sources. Older firms on the other hand may have burned through their initial cash reserves. The higher credit demand for exporters may be explained by a greater need for working capital. Taxation and corruption as growth obstacles lead to somewhat higher probabilities of the need for credit.

The impact of firm-ownership and exporting activity on credit demand is also economically relevant; according to our estimations state-owned firms are $13 \%$ less likely to need credit than private firms, foreign-owned firms are $12 \%$ less likely to need credit than domestic firms, while exporters are $6 \%$ more likely to need credit than non-exporters. The impact of the availability of internal funds is also economically significant: Firms that are one standard deviation more internally financed than the mean firm are around $11 \%$ less likely to need credit than the mean firm. By contrast, the (unexpected) positive relation between firm age and credit need is small in magnitude: Firms that are of average age in our sample (12.4 years old) are around 3\% more likely to need credit than the youngest firms in our sample, i.e. the three-year old firms.

The results from Models (2-4) suggest that the firm-level determinants of credit demand are similar in Eastern Europe to those in Western Europe. In particular, small, governmentowned, foreign-owned and internally financed firms are less likely to need credit in both regions. Moreover, the coefficients of our firm-level variables in Model (2) are mostly 
similar in size to those in Model (1), while the interaction terms of our firm-level variables with the region dummy Western Europe yield mostly statistically insignificant coefficients. Notable differences in credit demand between the two regions are that small firms and firms with more internal funding in Western Europe are less likely to need credit than similar firms in Eastern Europe. Also, privatized firms are more likely to need credit in Western than in Eastern Europe.

Our estimates suggest that in Eastern Europe small firms are 4\% less likely to need credit, while in Western Europe they are $11 \%$ less likely to need credit. This lower credit demand by small firms suggests that these firms may have either broader access to informal credit and internal funds, or that they have less investment opportunities. Responses to further questions in the BEEPS suggest that, for our sample of firms, informal financing is actually negligible compared to internal funding: Only 3\% of firms' investments are financed with informal loans. Moreover, with the variable Internal finance our estimates in Table 4 control for the availability of retained earnings as a funding source. The lower credit demand by small firms in our sample thus seems to be driven by less investment opportunities compared to larger firms.

Result 1: The determinants of credit needs are mostly similar in the two regions. Firms with alternative financings sources, i.e. government-owned, foreign-owned and internally financed firms, are less likely to need credit in both regions. Small firms are also less likely to need credit than larger firms, suggesting that they may have fewer investment opportunities. The latter finding is, however, weaker for Western Europe than for Eastern Europe. 


\section{B. Which firms are discouraged and which firms are denied credit?}

While $70 \%$ of the surveyed firms in Eastern Europe need credit, only $46 \%$ of them actually have credit. Table 1 suggests that most credit constrained firms, i.e. those which need, but do not have bank credit are discouraged from applying, rather than actually denied credit: $28 \%$ of the firms which need credit do not apply for credit, while only $8 \%$ of those who apply for credit have their applications rejected. In this section we examine which firms are discouraged from applying for credit and what discourages them from applying. We then look at which firms are denied credit after applying. Finally, we estimate the predicted rejection rates for those firms which were discouraged from applying for credit, in order to assess which share of these firms may have received credit.

Table 5 presents our regression results for loan application behavior. The dependent variable in this set of regressions is the dummy variable Discouraged. As in Table 4 we present separate estimates for Eastern Europe (column 1) and Western Europe (column 2) and then pool the data from both regions in column (3). In column (4) we again introduce, interaction effects of firm-level variables with the dummy variable Western Europe so as to compare the firm-level determinants between Eastern and Western Europe.

Insert Table 5 here

From our summary statistics in Table 1 we know that a large share of firms in each country does not need credit. Moreover, our results in Table 2 suggest that credit demand is related 
to firm size, ownership and activity. All models reported in Table 5 therefore control for selection effects at the loan demand stage. Each model includes the variable Mills ratio Need loan, which is the inverse of the Mills ratio estimated from our models of loan demand in Table $4 .{ }^{16}$ For identification purposes, we drop the variable Internal Finance from our regressions of loan discouragement, assuming that while access to internal financing may affect credit need, it should not affect the probability of firms to apply for credit, given that they need it.

The negative and significant coefficients estimated for Mills ratio - Need loan in Table 5 suggest that unobservable factors that increase the demand for credit tend to decrease the probability of being discouraged.

The results of Model (1) in Table 5 show that within Eastern Europe small firms and firms which operate in high-tax environments are more likely to be discouraged applying for a loan when they need one, while foreign owned, audited and bank-using firms are less likely to be discouraged. Again, the effects displayed in column (1) are economically significant. Small firms are $13 \%$ less likely to apply for loans than larger firms. Recalling that 72 percent of the firms apply for a loan in Eastern Europe, the estimated effect of firm size in discouraging loan applications is therefore substantial. At $-11 \%$ and $-7 \%$ the effects of foreign ownership, and audited financial accounts are also economically significant. Firms that are one standard deviation more bank-financed are $4 \%$ less likely to be discouraged.

\footnotetext{
${ }^{16}$ Our selection equations are estimated for each sample of firms separately: Models (1) and (2) in Table 5 use Models (1) and (2) from Table 4, respectively, while Models (3-4) in Table 5 use Model (3) from Table 4.
} 
The results for Models (2-4) suggest that loan discouragement differs between Eastern and Western Europe. We find that small firms are much less discouraged from applying for loans in Western Europe than in Eastern Europe. Small firms in Western Europe are 9 percentage points less likely to be discouraged for a loan than small firms in Eastern Europe (13 versus 4\%). The result that small Eastern European firms are less likely to apply for a loan than Western European firms, despite the fact that they need loans more often, is one of our key findings.

Model (4) in Table 5 also suggests that in Western Europe, government-owned firms and firms in high-tax environments are less likely to be discouraged, while firms with a higher share of earnings received through a bank account are more likely to be discouraged than in Eastern Europe. The difference in application behavior of government firms may be due to the fact that in Eastern Europe these firms possibly are able to rely more on government funding than in Western Europe.

What discourages so many firms which need credit from applying for a loan? Our summary statistics in Table 1 suggest that collateral requirements, perceived high interest rates, and burdensome application procedures all discourage a large share of potential borrowers. Table 6 examines which types of firms are discouraged by these three main factors. The table shows that small firms in Eastern Europe are discouraged more than large firms due to burdensome procedures and high interest rates, but surprisingly not due to strict collateral requirements. Moreover, both burdensome procedures and high interest rates are more likely to discourage small Eastern European firms than small firms in Western Europe.

The results presented in Table 6 suggest further that in Eastern Europe foreign owned firms and firms using bank accounts more often are less discouraged by procedures than domestic 
owned firms, while this is not the case in Western Europe. Also in Eastern Europe, audited firms are less likely to be discouraged by interest rates and collateral conditions than nonaudited firms, while this effect is weaker in Western Europe.

Insert Table 6 here

Taken together, these findings suggest that information asymmetries between banks and firms strongly affect credit discouragement in Eastern Europe compared to Western Europe. These results potentially demonstrate the importance of further improving institutions (i.e. credit bureaus) and regulations (corporate governance and accounting and corporate governance) which alleviate informational asymmetries.

The large share of discouraged firms, compared to those firms that apply and then are rejected credit, suggests that many firms may anticipate being rejected and not apply in the first place. We examine this conjecture by estimating hypothetical rejection rates for those firms which did not apply, i.e. discouraged firms.

We first estimate the firm-level determinants of loan rejection, using data for those firms that were not discouraged. Table 7 reports the results of this analysis in which the variable Rejected is related to firm-level explanatory variables, controlling for country and industry fixed effects. All models reported in Table 7 control for selection effects at the loan application (and loan demand) stage. Each model includes the variable Mills ratio Discouraged, which is the Mills ratio estimated from our models of Discouraged in Table 
5. ${ }^{17}$ For identification purposes we drop our indicators of the business environment Tax, Licensing \& permits, and Corruption from our regressions of Rejected, assuming that a firm's perception of its business environment may affect its loan application behavior but not the banks actual loan decision.

The coefficients reported in Table 7 suggest that among firms in our Eastern European sample, the rejection rate is higher for smaller, younger and privatized firms, while it is lower for exporting firms. The results from Model (4) suggest that government owned, foreign owned, privatized and audited firms in Western Europe are also less likely to be rejected than their counterparts in Eastern Europe.

Insert Table 7 here

The estimated coefficient for Mills-ratio discouraged displayed in Table 7 suggests that discouraged firms would have been more likely rejected, had they applied for a loan. Our predicted rejection rates for the sample of discouraged firms confirm this result. Based on the estimated coefficients in columns 1 and 2 of Table 7 we predict the rejection rates for the discouraged firms in Eastern and Western Europe separately.

\footnotetext{
${ }^{17}$ Our selection equations are estimated for each sample of firms separately: Models (1) and (2) in Table 6 use Models (1) and (2) from Table 5 respectively, while Models (3-4) in Table 6 use Model (3) from Table 5.
} 
In Table 8 we compare the predicted rejection rate for the discouraged firms to the actual rejection rate for the non-discouraged firms. Predicted rejection rates in both Eastern and Western Europe are higher, both statistically and economically speaking, than the actual rates, i.e. 12.0 versus $7.6 \%$, and 7.7 versus $4.7 \%$. This finding suggests that many firms rationally did not apply for loans as they anticipated that they would be rejected anyhow. Moreover, the higher discouragement rate in Eastern Europe may be partly explained by a larger share of possibly non-creditworthy firms. However, looked at from the other angle, these results suggest that the overwhelming share of discouraged firms in Eastern Europe, i.e. $88 \%$, may have received a loan had they applied.

Insert Table 8 here

Result 2: At the firm-level the higher rate of discouraged firms in Eastern Europe seems to be driven by a stronger reluctance of small and financially opaque firms to apply for a loan compared to Western Europe. While many discouraged firms correctly anticipate that their loan applications would be rejected, a large majority of discouraged firms seem to be creditworthy.

\section{Country-level determinants of discouragement and rejection}

Our summary statistics (Table 1) show that the share of firms which are discouraged from applying for a loan, as well as the firms that have their applications rejected is higher in Eastern Europe than in Western Europe. Moreover, our regression results in Tables (5-8) 
suggest the firm-level determinants of credit discouragement and rejection differ between Eastern and Western Europe. These findings are not that surprising, given that the macroeconomic environment and structural characteristics of the financial sector differ strongly between the two regions (see Table 3). In this section we look more closely at how inflation, foreign bank ownership, credit information sharing and creditor rights affect credit supply across Eastern and Western Europe.

In Table 9 we relate our five indicators of credit discouragement and credit rejection to our firm-level explanatory variables and our country-level indicators of the macroeconomic environment (Inflation), the ownership structure in the banking sector (Foreign banks) and creditor protection (Credit info, Creditor rights). Models (1-4) examine our indicators of discouragement, i.e. Discouraged, Discouraged-procedures, Discouraged-interest, and Discouraged-collateral, accounting for selection effects at the credit demand stage. ${ }^{18}$ Model 5 examines our indicator of credit rejection, i.e. Rejected, accounting for selection effects at the loan application stage. ${ }^{19}$ All models reported in the table control for industry fixed-effects; however, we drop the country fixed effects included in all previous regressions.

Insert Table 9 here

\footnotetext{
${ }^{18}$ We include the inverse of Mills ratio estimated from our model of Need loan in column 3 of Table 4, while for identification purposes we drop the variable Internal finance from our analysis.

${ }^{19} \mathrm{We}$ include the inverse of Mills ratio estimated from our model of Discouraged in column 3 of Table 7, while for identification purposes we drop the variables Tax, Licensing \& permits and Corruption from our analysis.
} 
Acknowledging the potential biases in our estimates due to omitted country-level variables, our results suggest that foreign ownership of the banking sector has a robust negative impact on loan application behavior. The estimated effects, suggest that going from the country with the weakest presence of foreign banks in Eastern Europe (Slovenia) to the country with the strongest presence of foreign banks (Slovakia) would increase the share of discouraged borrowers by $17 \%$. Hereby, the effect is strongest for the share of firms discouraged by high interest rates $(10 \%)$ and weakest for the share of firms discouraged by burdensome procedures (4.5\%). The results reported in Table 9 show no robust effect of inflation or creditor protection on credit discouragement.

The fact that discouragement is related to foreign bank presence, combined with our earlier result that small and opaque firms are most likely to be discouraged, seems to provide support for the conjecture that foreign banks "cherry-pick" in host country credit markets. In particular, our results on discouragement seem to support the hypothesis of Detragiache, Gupta and Tressel (2007) that foreign banks lend to large firms with credible financial statements rather than small, opaque firms. However, note that we find no significant effect of foreign bank presence on loan rejection rates. Thus while more firms may be discouraged due to the presence of foreign banks, this does not imply that more firms would have their loans applications denied.

Result 3: The higher rate of discouraged firms in Eastern Europe seems to be driven by the presence of foreign bank rather than differences in the macroeconomic environment or creditor protection. However, we find no evidence that foreign bank presence leads to stricter loan approval decisions. 


\section{Policy implications}

Summarizing our results we find that firms in Eastern Europe are equally likely to need credit as firms in Western Europe, but are more likely to be discouraged from applying for a loan. Firms in Eastern Europe are most discouraged by high interest rates, but also by collateral requirements and loan application procedures. Small firms and opaque firms are most likely to be discouraged, and well as firms in countries with a strong foreign bank presence. The loan approval rate for firms in Eastern Europe is similar to Western Europe. Moreover, it seems that most firms which are discouraged from applying for a loan, may have received a loan had they applied for one.

We draw three conclusions for policy from these results:

First, public policy aimed at increasing credit availability for firms in Eastern Europe should be aware that many firms across Eastern Europe, as in Western Europe, do not need bank credit to finance their operations and investments. Small firms, government-owned and foreign-owned firms are among those with lower need for credit while exportorientated firms have a higher credit demand.

Second, the majority of credit constrained firms are discouraged from applying for loans in the first place. Is loan discouragement a problem? As discouragement is particularly high among small and opaque firms, as well as in countries with a strong presence of foreign banks, it seems that firms perceive lending standards to have become more reliant on "hard information" with the entry of foreign banks. However, as we find that loan rejection rates are not related to foreign bank presence, it seems that the firms' perceptions of the likely lending conditions may be too pessimistic. Thus more transparency about credit eligibility 
and conditions may improve credit access, particularly in countries with a high presence of foreign banks.

Third, our results suggest that it is hard to determine how a credit crunch induced by the current financial crisis may impact economic performance across the region. On the one hand, our results suggest that small firms which dominate economic activity in the region are less reliant on bank credit, and thus may be less affected by the current crisis through the credit channel. On the other hand, we find that export orientated firms are in particular need of bank credit across the region. These firms, which are already hit hard by the decline in foreign demand, may thus also be among the worst hit victims of a credit crunch. 


\section{Bibliography}

Ai, C. R., and E. C. Norton E. C, 2003, Interaction Terms in Logit and Probit Models, Economics Letters, 80, 123-129.

Beck, T., A. Demirgüç-Kunt, and R. Levine, 2000, A New Database on Financial Development and Structure, World Bank Economic Review 14, 597-605.

Beck, T., A. Demirgüç-Kunt, L. Laeven, and R. Levine, 2008, Finance, Firm Size and Growth. Journal of Money, Credit and Banking 40, 1379-1405.

Bernard, A. B., and J. B. Jensen, 1999, Exceptional Exporter Performance: Cause, Effect, or Both?, Journal of International Economics 47, 1-25.

Bonin, J. P., I. Hasan, and P. Wachtel, 2005, Privatization Matters: Bank Efficiency in Transition Countries, Journal of Banking and Finance 29, 2155-2178.

Boyd, J. H., R. Levine, and B. D. Smith, 2001, The Impact of Inflation on Financial Sector Performance, Journal of Monetary Economics 47, 221-248.

Brown, M., T. Jappelli, and M. Pagano, 2009, Information Sharing and Credit: Firm-Level Evidence from Transition Countries, Journal of Financial Intermediation 18, 151-172.

Brown, M., S. Ongena, and P. Yesin, 2009, Foreign Currency Borrowing by Small Firms, CEPR, Discussion Paper No. 7540.

Cerqueiro, G., 2009, Bank Concentration, Credit Quality and Loan Rates, CentER-Tilburg University, Mimeo. 
Chakravarty, S., and J. S. Scott, 1999, Relationships and Rationing in Consumer Loans, Journal of Business 72, 523-544.

Chakravarty S., and M. Xiang, 2009, What Discourages Small Businesses from Asking for Loans? The International Evidence on Borrower Discouragement, Purdue University, Mimeo.

Chari, A., and P. B. Henry, 2004, Risk Sharing and Asset Prices: Evidence from a Natural Experiment, Journal of Finance 59, 1295-1324.

Clerides, S. K., S. Lach, and J. Tybout, 1998, Is Learning by Exporting Important? MicroDynamic Evidence from Colombia, Mexico, and Morocco, Quarterly Journal of Economics 113 (3), 903-947.

Cole, R., 1998, The Importance of Relationships to the Availability of Credit, Journal of Banking and Finance 22, 959-977.

Cole, R. A., 2008, Who Needs Credit and Who Gets Credit? Evidence from the Surveys of Small Business Finances, DePaul University, Mimeo.

de Haas, R., and I. Lelyveld, 2006, Foreign Banks and Credit Stability in Central and Eastern Europe. A Panel Data Analysis, Journal of Banking and Finance 30, 1927-1952.

Detragiache, E., T. Tressel, and P. Gupta, 2008, Foreign Banks in Poor Countries: Theory and Evidence, Journal of Finance 63, 2123-2160.

Dewatripont, M., and E. Maskin, 1995, Credit and Efficiency in Centralized and Decentralized Economies, Review of Financial Studies 62, 541-555. 
Djankov, S., C. McLiesh, and A. Shleifer, 2007, Private Credit in 129 Countries, Journal of Financial Economics 84, 299-329.

EBRD, 2006, Transition Report 2006: Finance in Transition, European Bank for Reconstruction and Development.

EBRD, 2008, Mortgages in Transition Economies, European Bank for Reconstruction and Development.

Fries, S., and A. Taci, 2002, Banking Reform and Development in Transition Countries, EBRD, Working Paper No. 71.

Fries, S., and A. Taci, 2005, Cost Efficiency of Banks in Transition: Evidence from 289 Banks in 15 Post-communist Countries, Journal of Banking and Finance 29, 55-81.

Gertner, R. H., D. S. Scharfstein, and J. Stein, 1994, Internal versus External Capital Markets, Quarterly Journal of Economics 109, 1211-1230.

Giannetti, M., and S. Ongena, 2008, Lending by Example: Direct and Indirect Effects of Foreign Bank Presence in Emerging Markets, CentER - Tilburg University, Mimeo.

Giannetti, M., and S. Ongena, 2009, Financial Integration and Firm Performance: Evidence from Foreign Bank Entry in Emerging Markets, Review of Finance 13, 181-223.

Guiso, L., P. Sapienza, and L. Zingales, 2004, Does Local Financial Development Matter?, Quarterly Journal of Economics 119, 929-970. 
Han, L., S. Fraser, and D. J. Storey, 2009, Are Good or Bad Borrowers Discouraged from Applying for Loans? Evidence from US Small Business Credit Markets, Hull University Business School, Mimeo.

Jappelli, T., 1990, Who Is Credit Constrained in the US Economy?, Quarterly Journal of Economics 105, 219-234.

Klapper, L., V. Sarria-Allende, and V. Sulla, 2002, Small- and Medium-Size Enterprise Financing in Eastern Europe, World Bank, Policy Research Working Paper No. 2933.

Kon, Y., and D. J. Storey, 2003, A Theory of Discouraged Borrowers, Small Business Economics 21, 37-49.

Kornai, J., 1979, Resource-Constrained versus Demand-Constrained Systems, Econometrica 47, 801-819.

Khwaja, A. I., A. Mian, and B. H. Zia, 2007, Dollars Dollars Everywhere and Not a Dime to Lend, Harvard University, Mimeo.

La Porta, R., Lopez-de-Silanes, F. Shleifer, A., and R. Vishny, 1998, Law and Finance, Journal of Political Economy 106, 1113-1155.

Laeven, L., and F. Valencia, 2008, Systemic Banking Crises: A New Database, IMF, Working Paper.

Levine, R., 2006, Finance and Growth: Theory and Evidence, in Handbook of Economic Growth, Eds: P. Aghion and S. Durlauf, New York: Elsevier North-Holland, 865-934.

Mauro, P., 1995, Corruption and Growth, Quarterly Journal of Economics 110, 681-712. 
Mester, L.J., and L. Nakamura and M. Renault, 2007, Transactions Accounts and Loan Monitoring, Review of Financial Studies 20, 529-556.

Ongena, S., and A. Popov, 2009, Interbank Market Integration, Loan Rates, and Firm Leverage, European Central Bank, Mimeo.

Pistor, K., M. Raiser, and S. Gelfer, 2000, Law and Finance in Transition Economies, Economics of Transition 8, 325-368.

World Bank, 2008, Doing Business 2009: Comparing Regulation in 181 Countries. 


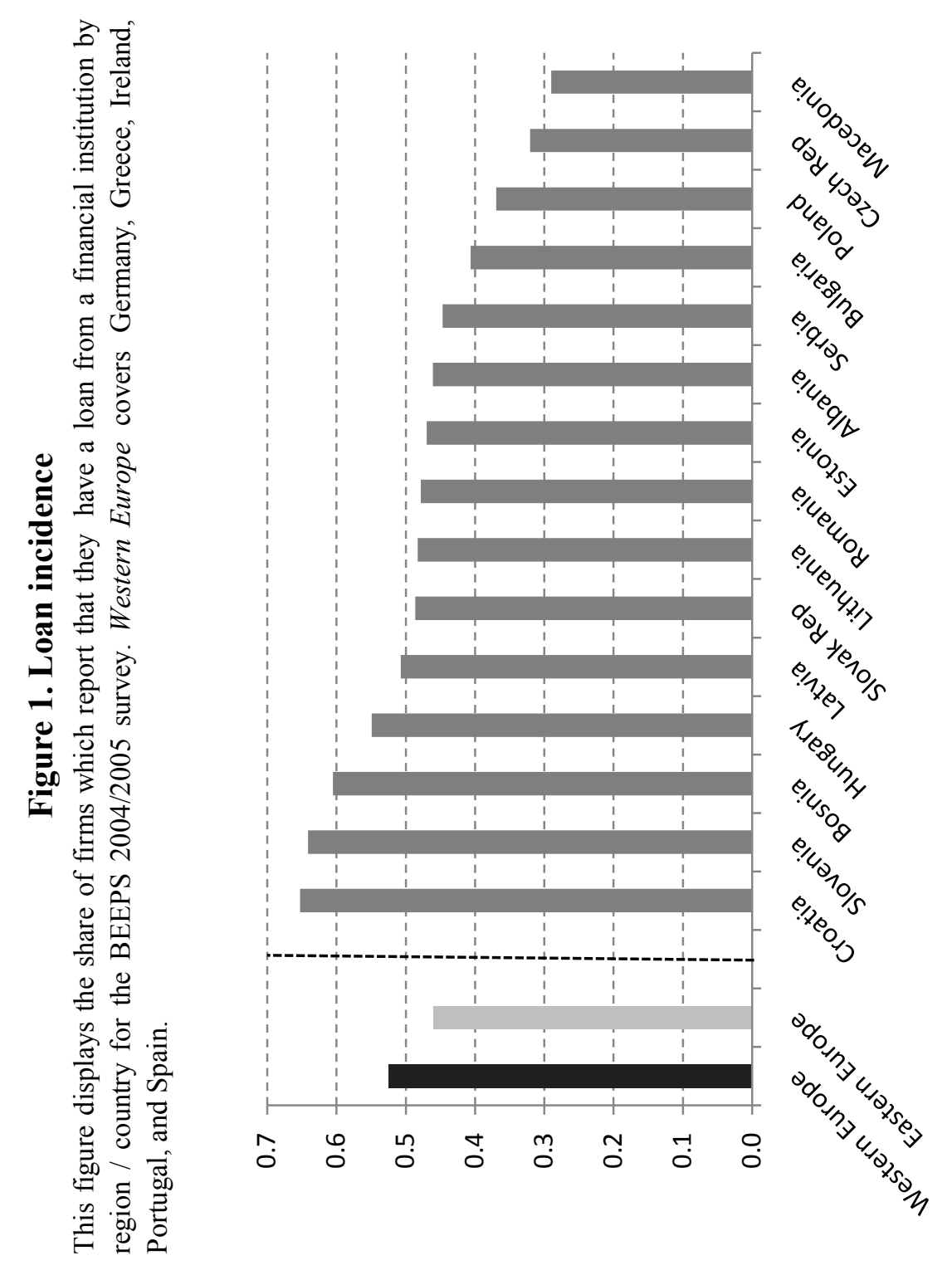




\section{Figure 2. Responses to BEEPS questions on credit access}

The figure summarizes the responses of firms to questions Q46a, Q47a and Q47b of the 2004/2005 BEEPS survey. Q46a elicits whether firms have currently have a loan from a financial institution. For those which do not have a loan Q47a elicits whether the firm (i) did not apply for a loan, (ii) applied for a loan but was rejected, or (iii) has a loan application pending. For those firms that did not apply for a loan Q47b elicits the reason(s) for not applying.

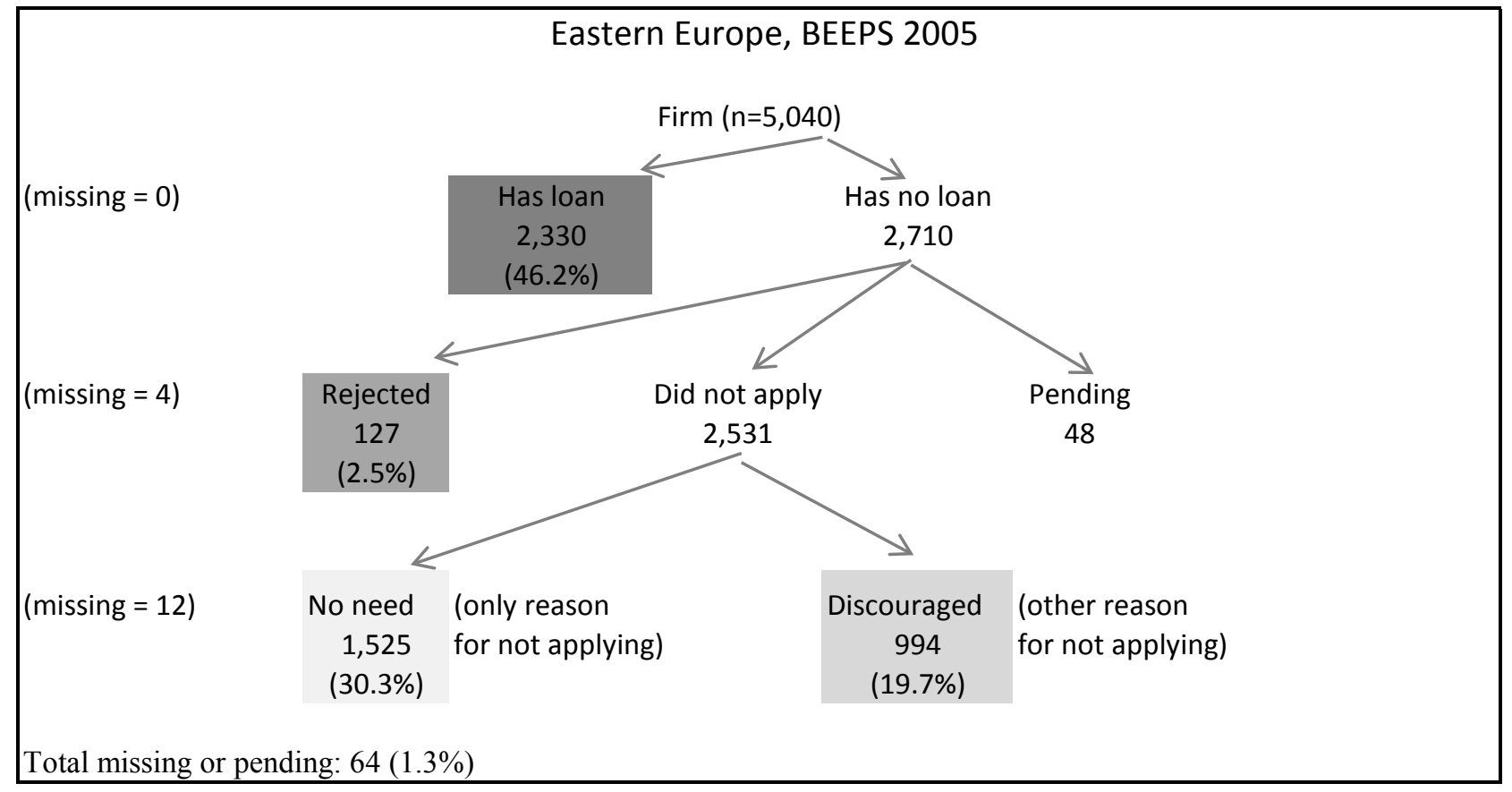

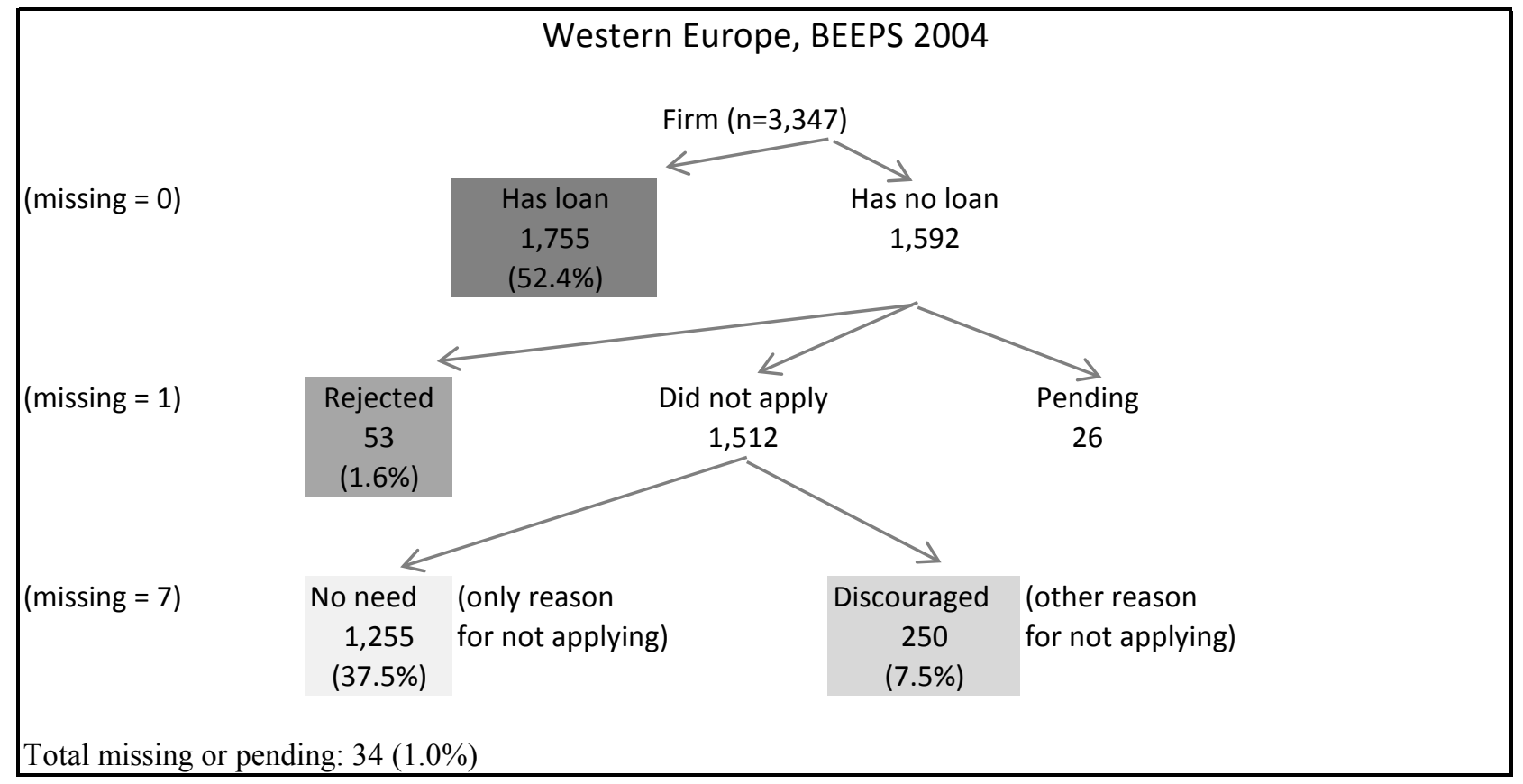

Need loan $=0$

Need loan $=1$, Discouraged $=1$

Need loan $=1$, Discouraged $=0$, Rejected $=1$

Need loan $=1$, Discouraged $=0$, Rejected $=0$ 


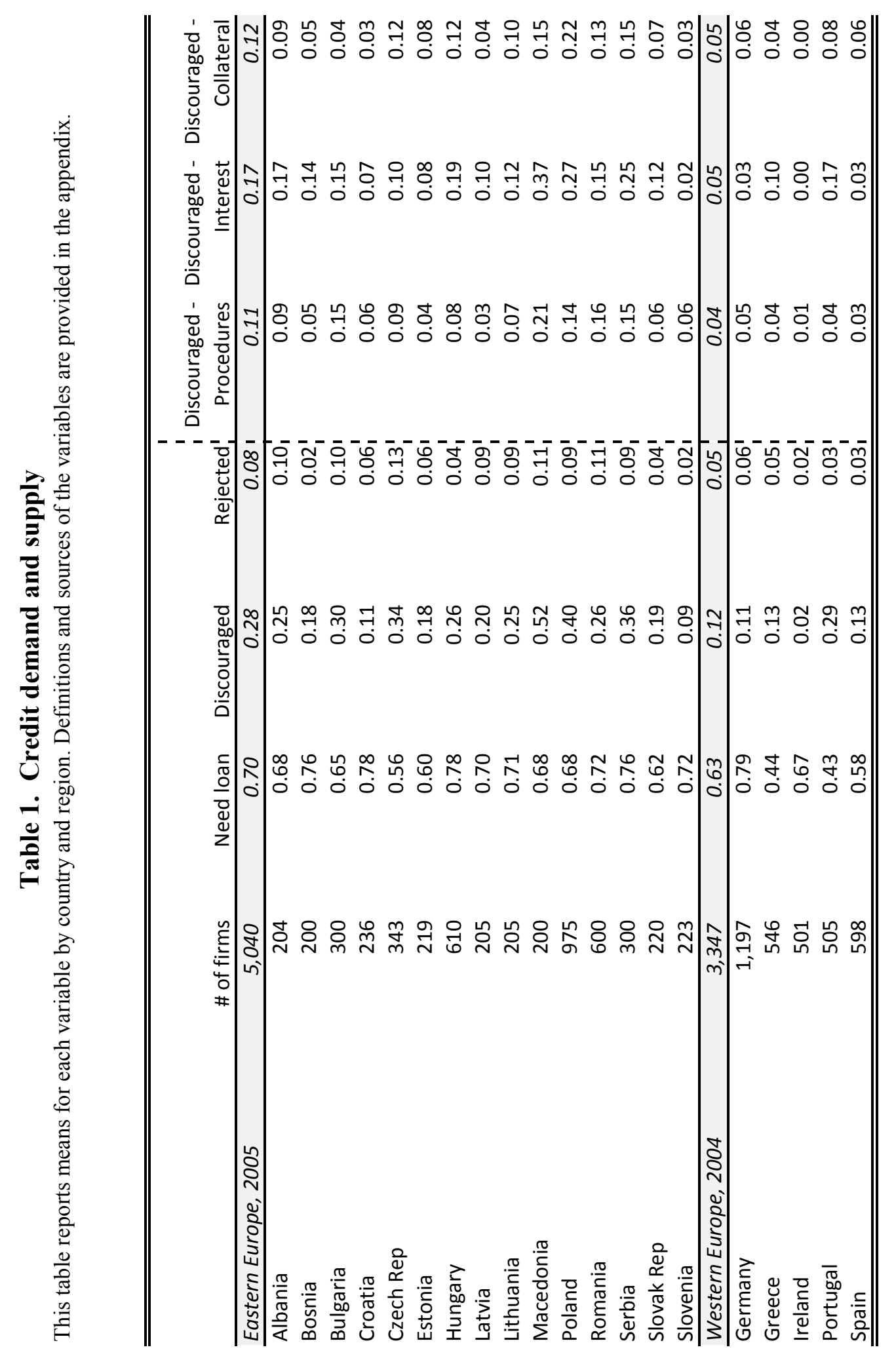




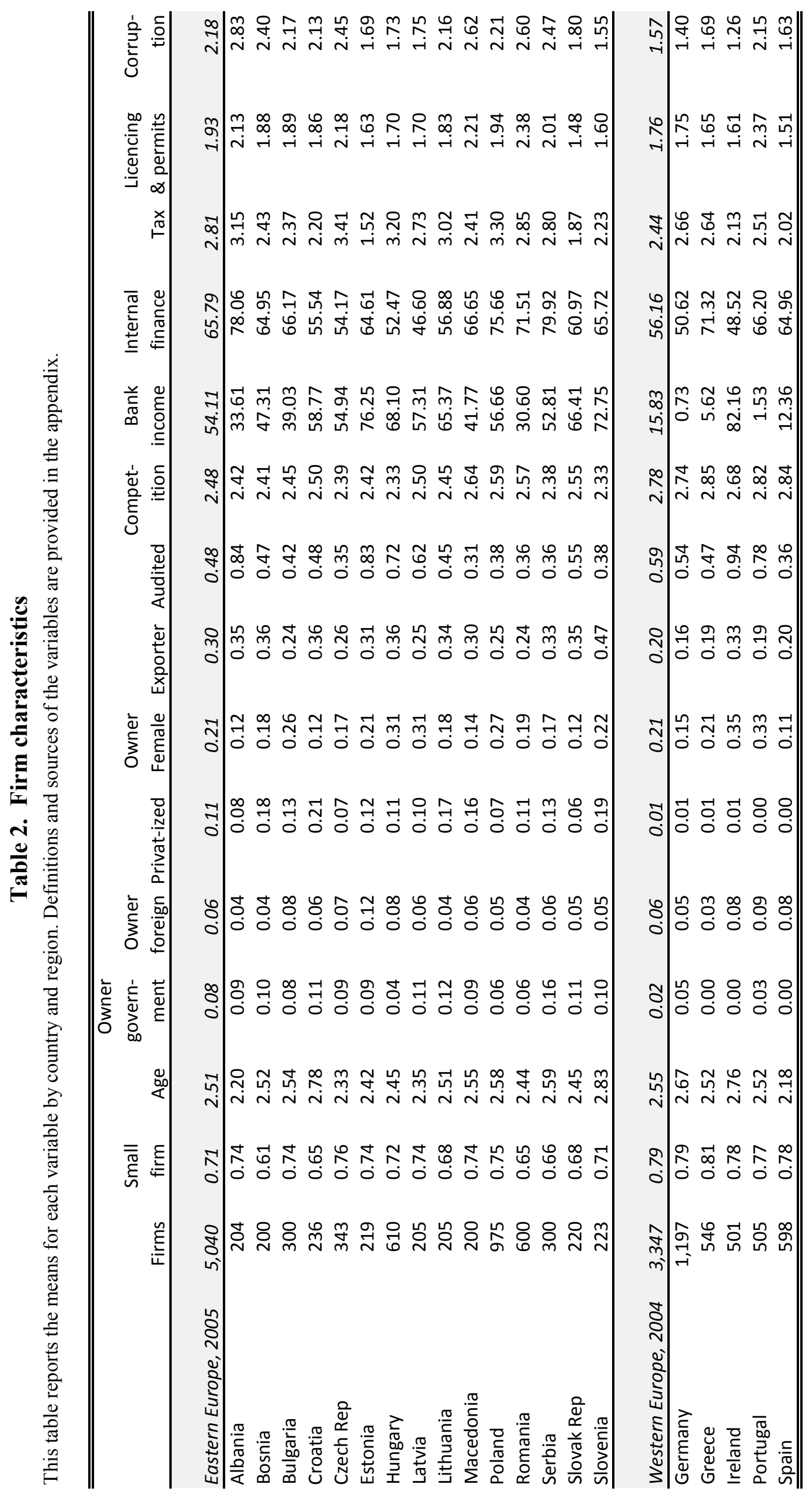


Table 3. Country characteristics

This table reports means for each variable by country and region (Panel A) as well as pairwise correlations (Panel B). Data for 2005 are 2003-2005 averages. Data for 2004 are 2002-2004 averages. The regional averages are unweighted averages across countries. Definitions and sources of the variables are provided in the appendix.

Panel A. Means per country and region

\begin{tabular}{lrrrr}
\hline \hline & Inflation & Foreign banks & Credit info & Creditor rights \\
\hline Eastern Europe, 2005 & 4.39 & 72.1 & 3.4 & 6.8 \\
\hline Albania & 2.43 & 77.6 & 0.0 & 9.0 \\
Bosnia & 1.47 & 83.8 & 5.0 & 4.0 \\
Bulgaria & 5.41 & 79.6 & 3.3 & 8.0 \\
Croatia & 2.71 & 91.2 & 0.0 & 4.5 \\
Czech Rep & 2.01 & 85.2 & 4.3 & 7.0 \\
Estonia & 3.21 & 98.3 & 5.0 & 6.0 \\
Hungary & 4.84 & 76.4 & 5.0 & 7.0 \\
Latvia & 5.99 & 53.2 & 2.3 & 9.0 \\
Lithuania & 1.47 & 92.7 & 4.0 & 5.0 \\
Macedonia & 1.04 & 48.5 & 3.0 & 7.0 \\
Poland & 2.22 & 72.4 & 4.0 & 8.0 \\
Romania & 10.65 & 57.5 & 4.3 & 6.5 \\
Serbia & 12.73 & 47.4 & 5.0 & 5.5 \\
Slovak Rep & 6.34 & 96.8 & 3.0 & 9.0 \\
Slovenia & 3.39 & 20.5 & 3.0 & 6.0 \\
\hline Western Europe, 2004 & 2.83 & 20.7 & 4.8 & 5.6 \\
\hline Germany & 1.49 & 5.9 & 6.0 & 8.0 \\
Greece & 3.26 & 24.3 & 4.0 & 3.0 \\
Ireland & 3.18 & 35.8 & 5.0 & 8.0 \\
Portugal & 2.95 & 26.3 & 4.0 & 3.0 \\
Spain & 3.29 & 11.3 & 5.0 & 6.0 \\
\hline \hline
\end{tabular}

Panel B. Pairwise correlations

\begin{tabular}{lrrrr}
\hline \hline & Inflation & Foreign banks & Credit info & Creditor rights \\
\hline Inflation & 1 & & & \\
Foreign banks & -0.01 & 1 & 1 & \\
Credit info & 0.11 & -0.32 & -0.16 & 1 \\
Creditor rights & 0.10 & 0.16 & & \\
\hline \hline
\end{tabular}




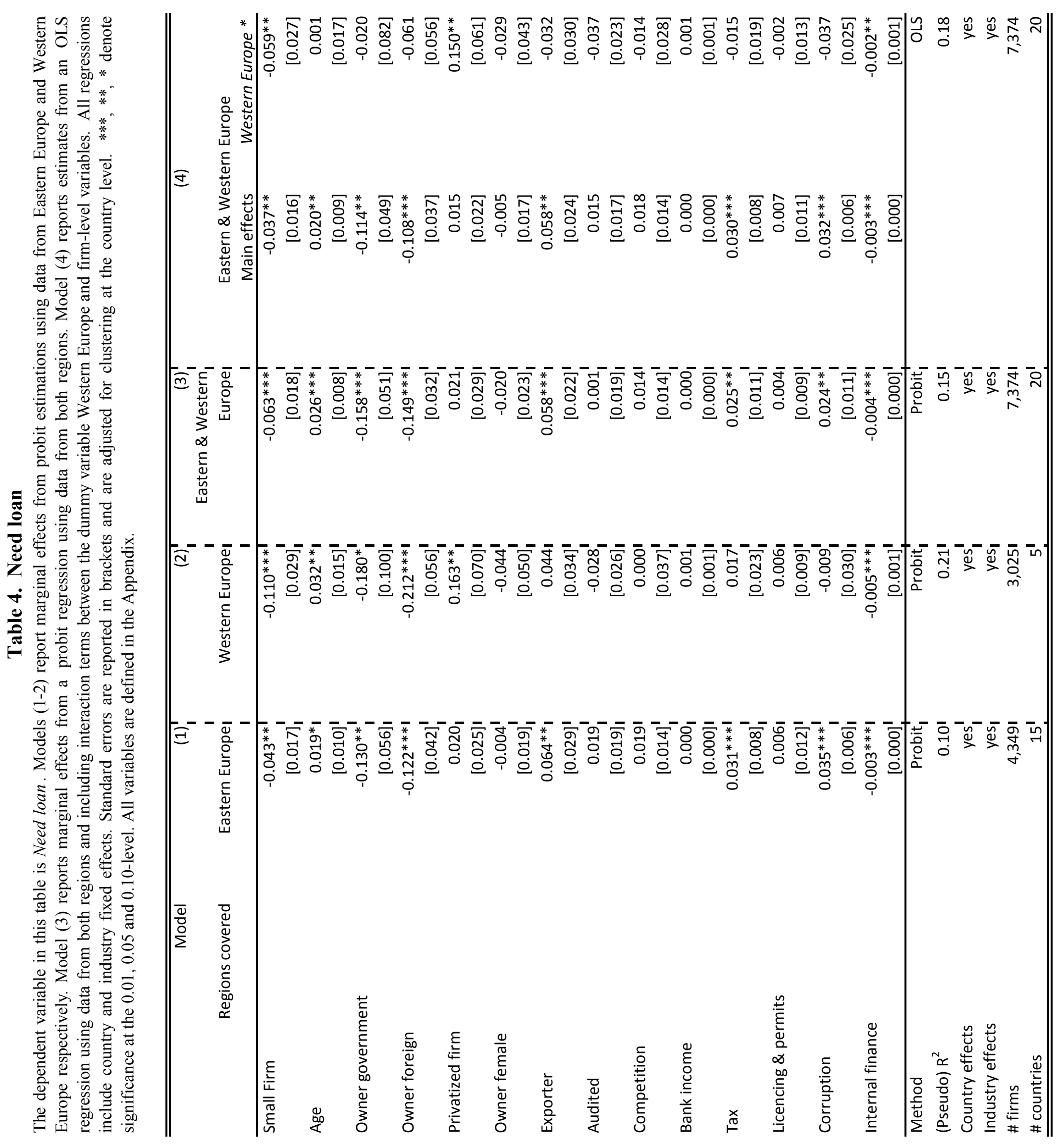




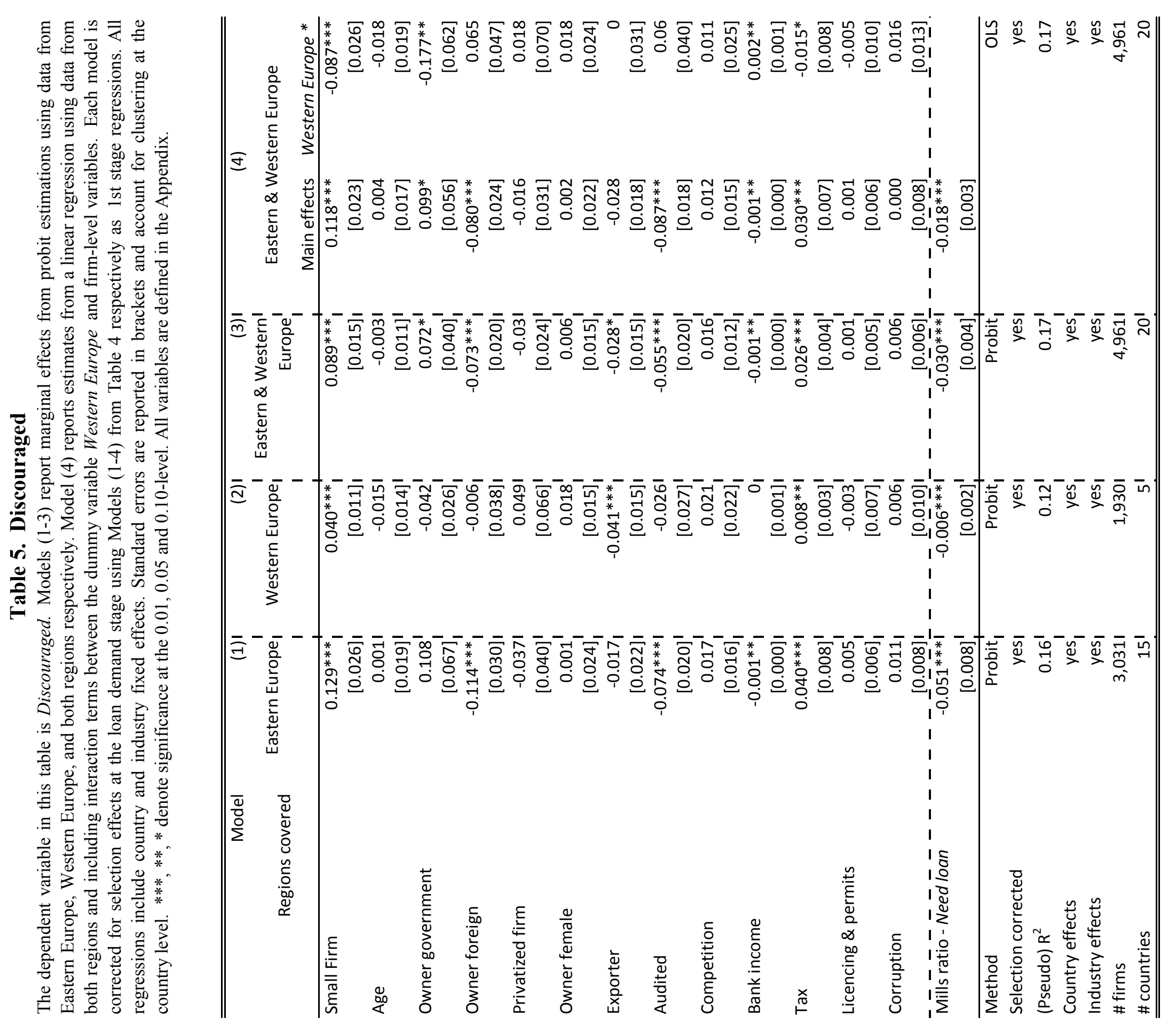




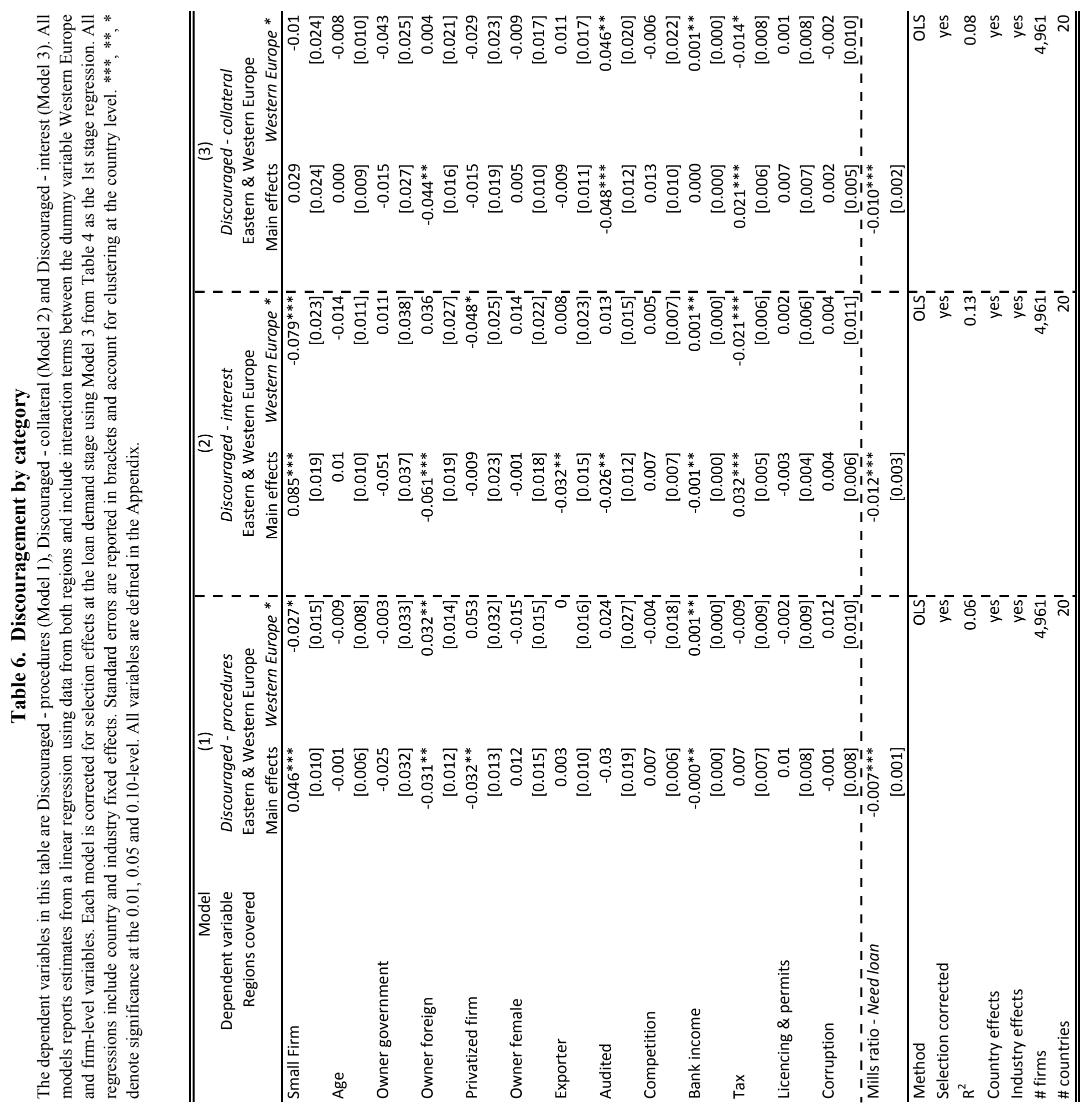




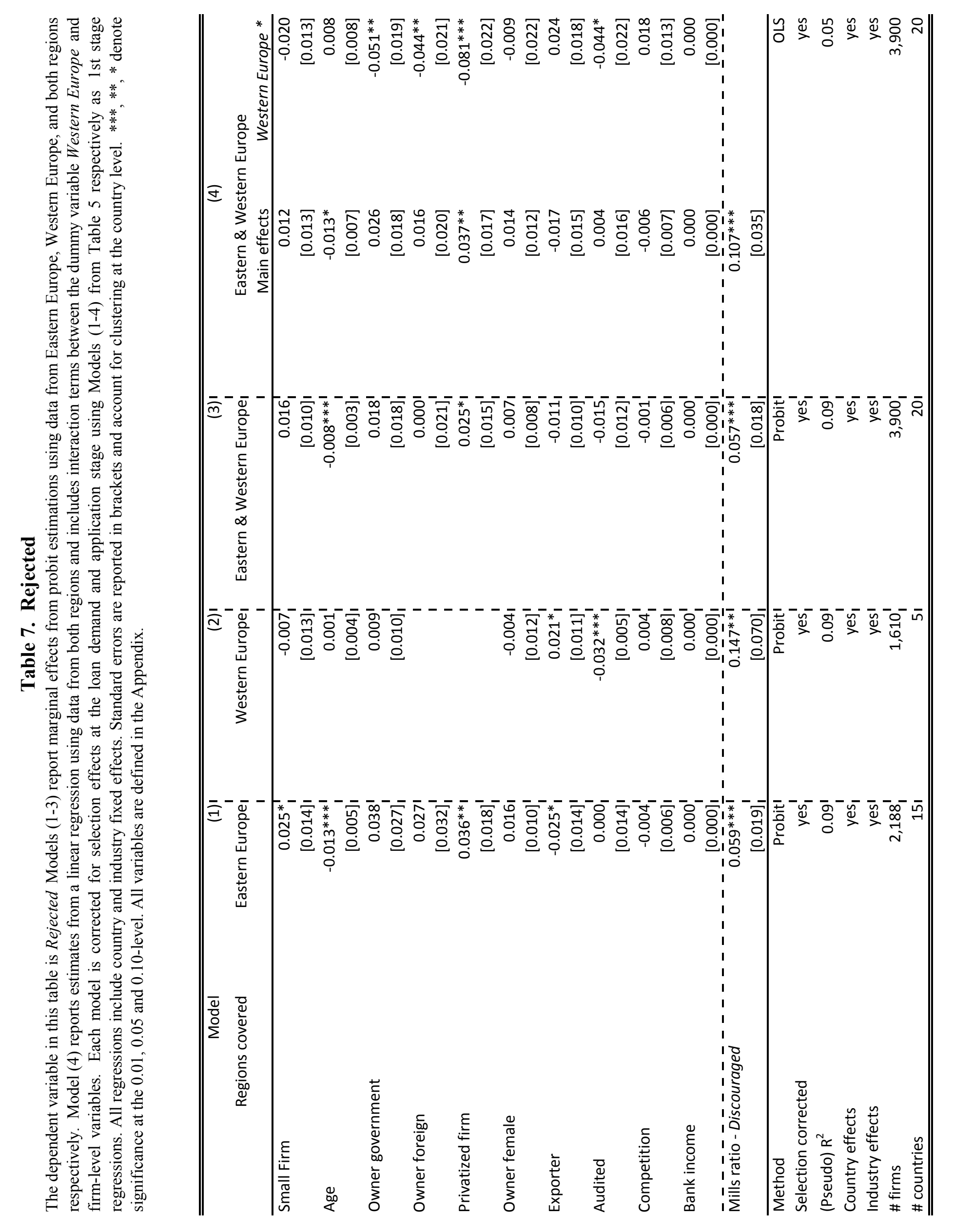




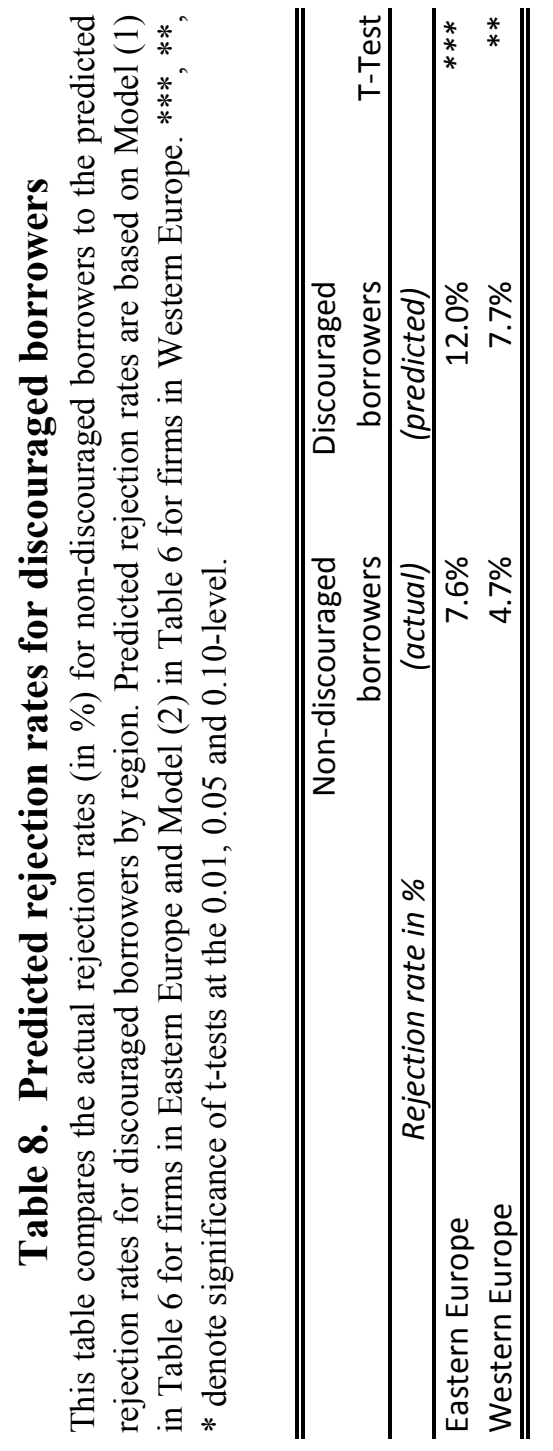




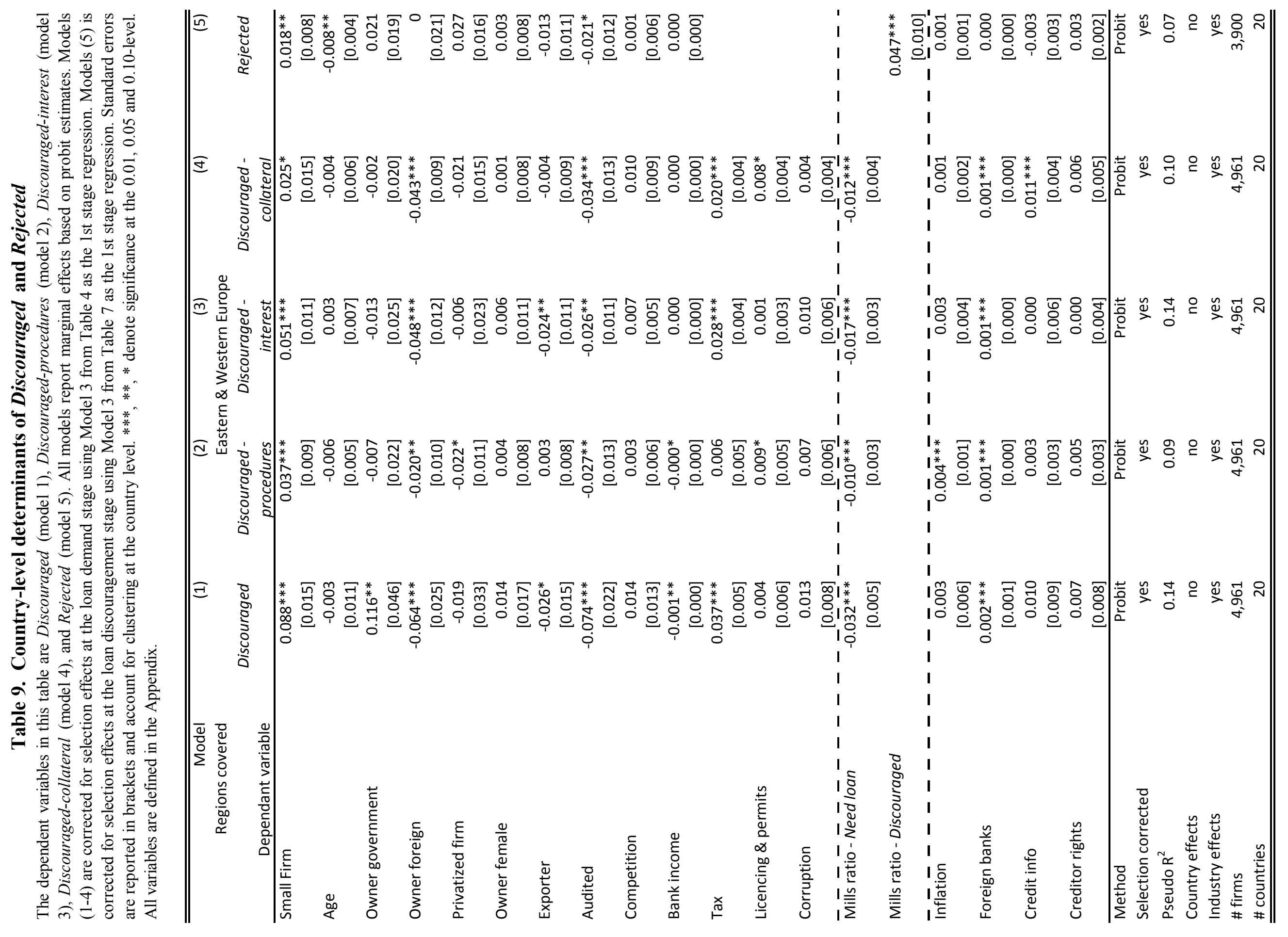




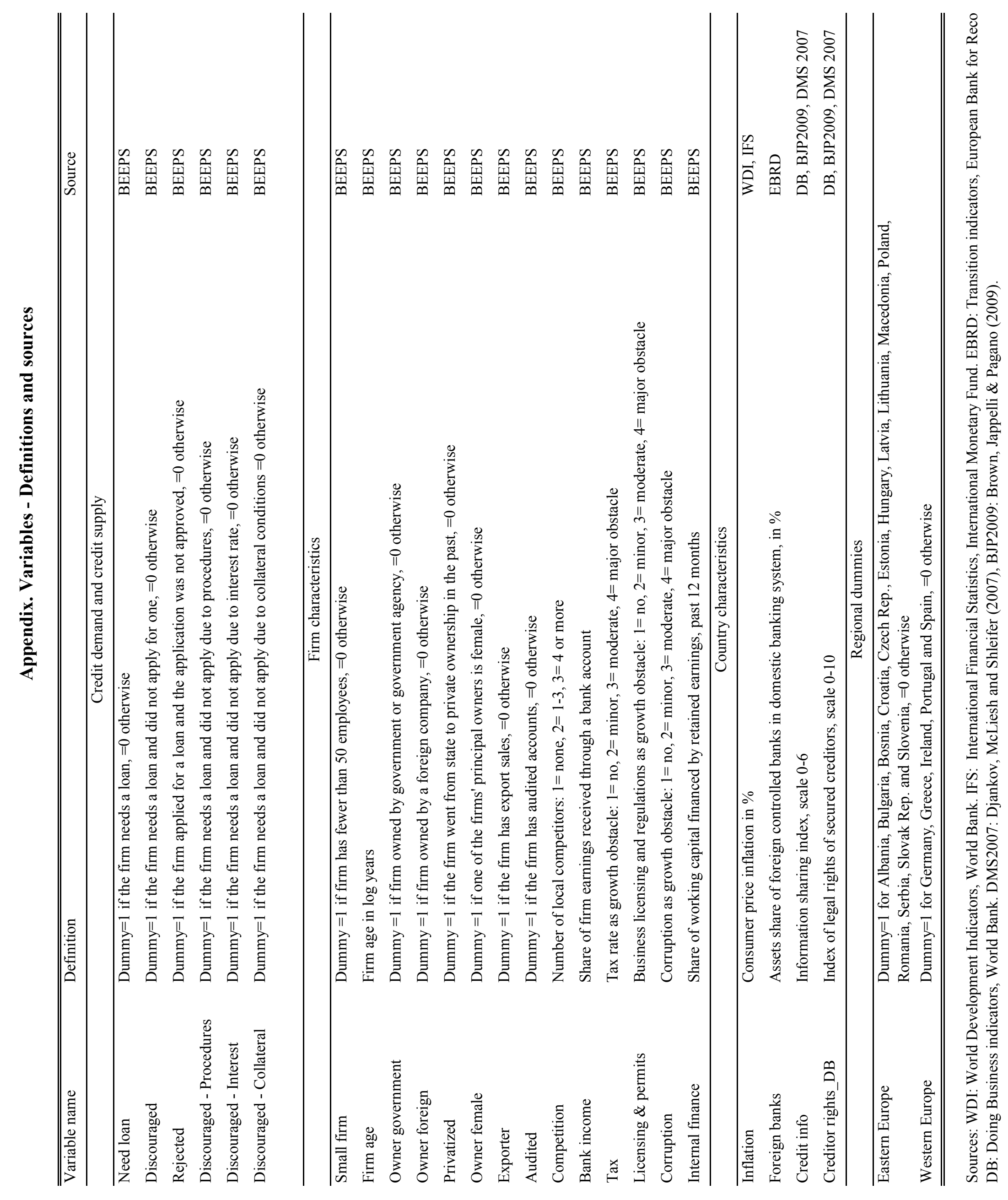

